\title{
Existence of functional lingual antimicrobial peptide in bovine milk
}

\author{
N. Isobe, ${ }^{1}$ J. Nakamura, H. Nakano, and Y. Yoshimura \\ Graduate School of Biosphere Science, Hiroshima University, Higashi-Hiroshima, 739-8528 Japan
}

\begin{abstract}
The lingual antimicrobial peptide (LAP) belongs to the $\beta$-defensin family in cattle and is localized in epithelial cells of alveoli in mammary glands. The aim was to investigate whether LAP is secreted into milk and whether the secreted LAP has antimicrobial activity. Decaseinated bovine skim milk was applied to sample extraction cartridges, and the eluate was used for competitive enzyme immunoassay and Western blotting to test for the presence of LAP in milk. After tricine-SDS PAGE, the gel was stained using the periodic acid-Schiff reaction to examine the possibility of glycosylation of LAP. The eluate obtained from the sample extraction cartridges was subjected to a LAP antibody-coupled affinity column, after which the antimicrobial activity of its eluate against Escherichia coli was investigated with radial diffusion plate assay and colony-forming unit enumeration following the culture of bacteria with the sample. The immunoreactive LAP was detected in the eluate by competitive enzyme immunoassay (optical density $=0.437 \pm 0.012$ vs. $0.468 \pm 0.016$ ). In the Western blotting analysis, immunoreactive bands were seen around 8, 14, and $17 \mathrm{kDa}$. The bands at 14 and 17 $\mathrm{kDa}$, but not $8 \mathrm{kDa}$, were periodic acid-Schiff reactionpositive. The eluate of LAP antibody-coupled affinity column had antimicrobial activity against E. coli (cfu/ control $=0.17 \pm 0.18)$. These results suggest that bovine milk contains functional LAP-like substances that exert antimicrobial activity.
\end{abstract}

Key words: lingual antimicrobial peptide, milk, bovine, defensin

\section{INTRODUCTION}

Mastitis is a serious disease of dairy cows, caused by bacterial infection of the mammary gland, that has detrimental effects on the quantity and quality of milk. To prevent infections, mammary glands prepare sequentially orchestrated mechanisms of immunity. Innate immunity plays an important role in the first defense system against infection in the mammary gland as well as the entire body. This type of immunity consists of various antimicrobial proteins such as lactoperoxidase,

Received December 2, 2008

Accepted January 19, 2009

${ }^{1}$ Corresponding author: niso@hiroshima-u.ac.jp lysozyme, and lactoferrin (Polis and Shmukler, 1953; Chandan et al., 1964; Bellamy et al., 1993). These proteins kill bacteria in different ways; for example, lactoferrin chelates iron ions essential for bacterial growth. The antimicrobial peptide defensin is found in the innate immunity systems of mammals (Ganz et al., 1985; Selsted and Ouellette, 2005). Defensin causes permeabilization of target bacteria membranes, resulting in cell lysis and eventual bacterial death (Ganz, 2003). Both gram-negative and gram-positive bacteria can be the target of defensin (Schonwetter et al., 1995).

The bovine $\beta$-defensin includes lingual antimicrobial peptide (LAP; Schonwetter et al., 1995), bovine neutrophil $\beta$-defensin (Selsted et al., 1993; Goldammer et al., 2004), tracheal antimicrobial peptide (Diamond et al., 1991), and enteric $\beta$-defensin (Tarver et al., 1998). Lingual antimicrobial peptide was first isolated from inflamed bovine tongue epithelium (Schonwetter et al., 1995). Stolzenberg et al. (1997) found widely spread LAP mRNA expression in infected bovine intestinal and respiratory tissues. The expression of $\beta$-defensin mRNA was reported in the mammary glands of cows (Swanson et al., 2004). A positive relationship between SCC in milk and LAP mRNA expression and localization of mRNA in epithelial cells of mastitic tissue by in situ hybridization was described. Singh et al. (2008) reported an increase in LAP mRNA expression in the bovine alveolar tissue at $192 \mathrm{~h}$ postmilking upon involution. Immunohistochemical studies demonstrated the expression of LAP peptide in healthy (Isobe et al., 2009) and Escherichia coli-inoculated mammary tissues (Petzl et al., 2008).

Jia et al. (2001) and Armogida et al. (2004) reported abundant human $\beta$-defensin- 1 and 2 in human milk. If the milk of healthy cows contains LAP, it may play roles not only in the defense of mammary tissues, but also in neonatal immunity. Nevertheless, it is not clear whether the LAP peptide is secreted from mammary tissue into the milk. Therefore, the present study was undertaken to identify the presence of LAP peptide in bovine milk.

\section{MATERIALS AND METHODS}

\section{Milk Sample Preparation}

Milk was collected twice by machine from a HolsteinFriesian dairy cow ( $\mathrm{n}=1 ; 3$ yr old) at the Hiroshima 
University Farm. The cow was fed in accordance with the regulations of Hiroshima University for animal experiments. The cow was multiparous and several months postpartum (early stage of lactation). The composite milk with low SCC $(<100,000$ cells/mL) was used. Removal of fat and casein was performed as described previously (Bushe and Oliver, 1987). Fresh raw milk was heated at $100^{\circ} \mathrm{C}$ for 5 min and skimmed by centrifugation at $1,700 \times g$ for $30 \mathrm{~min}$ at $4^{\circ} \mathrm{C}$. The casein was removed by addition of acetic acid until $\mathrm{pH}$ $=4.5$ and centrifugation. The supernatant was loaded into C18 Sep-Pak cartridges (Waters Corp., Milford, MA). Elution was achieved by flow of $80 \%$ acetonitrile in $0.1 \%$ trifluoroacetic acid followed by evaporation.

\section{Competitive Enzyme Immunoassay}

An enzyme immunoassay procedure was performed as described previously (Isobe et al., 2009) with minor modifications. A 96-well microtiter plate was coated with $2 \mu \mathrm{g} / \mathrm{mL}$ anti-LAP antibody in carbonate buffer (pH 9.7) at $4^{\circ} \mathrm{C}$ overnight, followed by blocking with $0.05 M$ borate buffer supplemented with $0.2 \%$ BSA at $\mathrm{pH}$ 7.8. Evaporated samples were resuspended in the borate buffer and $0.05 \mathrm{~mL}$ was pipetted into wells with incubation for $2 \mathrm{~h}$ at room temperature. After washing 4 times with PBS, the wells were incubated with 0.05 $\mathrm{mL}$ of horseradish peroxidase-labeled LAP for $1 \mathrm{~h}$. The wells were washed with PBS and incubated with 0.15 $\mathrm{mL}$ of tetramethyl benzidine solution for $30 \mathrm{~min}$. The optical density was measured at $655 \mathrm{~nm}$. The assay was repeated 3 times.

\section{Western Blotting}

Evaporated eluate of the Sep-Pak cartridges was mixed with sample buffer followed by immersion into boiling water as described previously (Yoshimura and Bahr, 1991). The sample $(0.01 \mathrm{mg})$ was electrophoresed on tricine-SDS PAGE gels containing 15\% acrylamide (Schagger and von Jagow, 1987), and electroblotted onto nitrocellulose membrane (GE Healthcare, Uppsala, Sweden). For immunodetection, the membrane was blocked with Tris-buffered saline supplemented with $0.5 \%$ Triton X-100 and $1 \%$ goat serum for $1 \mathrm{~h}$, and cultured with anti-LAP antibody at $1 \mu \mathrm{g} / \mathrm{mL}$ overnight at $4^{\circ} \mathrm{C}$. The membrane was cultured with $5 \mu \mathrm{L} / \mathrm{mL}$ anti-rabbit IgG antibody labeled with biotin (Vector Laboratories Inc., Burlingame, CA). The avidin-biotincomplex reaction was then performed using a Vectastain $\mathrm{ABC}$ kit (Vector Laboratories Inc.) for visualization of immunoreacted bands using diaminobenzidine solution consisting of $0.02 \%$ (wt/vol) 3, 3'-diaminobenzidine tetrahydrochloride and $0.005 \%$ (vol/vol) $\mathrm{H}_{2} \mathrm{O}_{2}$ in $0.05 \mathrm{M}$ Tris-HCl buffer, $\mathrm{pH}$ 7.6. Blotting was repeated twice.

\section{Carbohydrate Staining of Milk Peptides}

Carbohydrate staining was performed as reported (Cagatay and Hickford, 2008). Immediately following electrophoresis, the gels were washed in $50 \%$ ( $\mathrm{vol} / \mathrm{vol}$ ) ethanol for $30 \mathrm{~min}$ and fixed for 1 to $2 \mathrm{~h}$ using a fixation solution (10\% acetic acid and $35 \%$ methanol). The gels were placed in periodate solution $[7 \mathrm{~g} / \mathrm{L}$ periodic acid $\left(\mathrm{H}_{5} \mathrm{IO}_{6}\right)$ in $5 \%$ (vol/vol) acetic acid] for $30 \mathrm{~min}$ before washing 6 times in distilled water for 5 min per wash. A sodium metabisulfite solution $\left[2 \mathrm{~g} / \mathrm{L} \mathrm{Na}_{2} \mathrm{~S}_{2} \mathrm{O}_{5}\right.$ in $5 \%$ acetic acid] was added to the gels and allowed to react for 5 to $10 \mathrm{~min}$. Fresh sodium metabisulfite solution was then added and left for another 5 to $10 \mathrm{~min}$. The gels were placed in Schiff's reagent and incubated in the dark at room temperature until red or magenta bands appeared $(2 \mathrm{~h})$. The gels were then washed with $0.1 \%$ (wt/vol) $\mathrm{Na}_{2} \mathrm{~S}_{2} \mathrm{O}_{5}$ in $10 \mathrm{mM} \mathrm{HCl}$ for $6 \mathrm{~h}$ in the dark.

\section{LAP Peptide Purification by Anti-LAP Antibody-Coupled Affinity Column}

Anti-LAP antibody was purified by the HiTrap $N$-hydroxysuccinimide-activated high-performance affinity column (GE Healthcare) coupled with synthetic peptide (RNSQSCRRNKG; 11 amino acids out of 40 amino acids of mature peptide; Schonwetter et al., 1995) according to the manufacturer's directions. This affinity-purified LAP antibody was further coupled to the HiTrap $N$-hydroxysuccinimide-activated HP affinity column. Decaseinated skim milk was subjected to this affinity column to purify LAP peptide in the milk. Eluted LAP peptide was tested for antimicrobial activity.

\section{Antimicrobial Activity}

Antimicrobial activity was examined by 2 methods using E. coli (IFO3301); the first was a radial diffusion plate assay as described by Zasloff (1987), and the second was colony-forming unit enumeration after the culture of bacteria with the sample. In the former method, cultured bacteria were added to $10 \mathrm{~mL}$ of $0.7 \%$ agar in nutrient broth and poured over a $90-\mathrm{mm}$ Petri dish containing $10 \mathrm{~mL}$ of nutrient agar $(\mathrm{pH} 7,1.5 \%$ agar, Eiken Chemical Co., Tokyo, Japan). Antibacterial activity was assayed by suppression of bacterial growth dependent on application of fractions $(2 \mu \mathrm{L})$ to the top agar surface.

The quantitative antimicrobial activity of the sample was determined as follows. Cultured bacteria were washed with $0.01 \mathrm{M}$ phosphate buffer thrice and resuspended in the same buffer. The cell concentrations were 


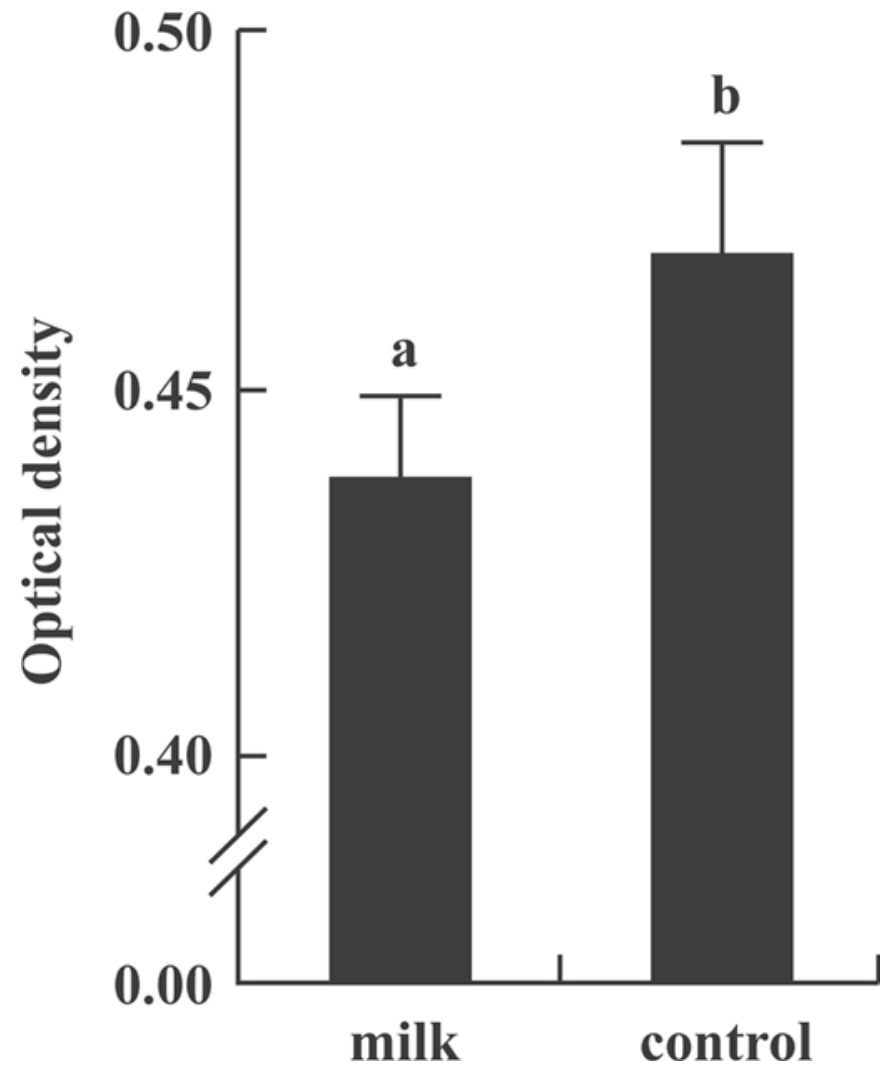

Figure 1. Competitive enzyme immunoassay of bovine SepPak eluted milk proteins. The control is the buffer without milk. ${ }^{\mathrm{a}, \mathrm{b}}$ Different letters indicate significant difference in optical densities between groups $(P<0.05)$.

estimated by measuring the optical density at $600 \mathrm{~nm}$. The suspensions were diluted to $1 \times 10^{7} \mathrm{cfu} / \mathrm{mL}$ and mixed with the sample, followed by incubation at $37^{\circ} \mathrm{C}$ for $3 \mathrm{~h}$. Serial 10-fold dilutions of the suspension were performed using phosphate buffer and surface-plated onto nutrient agar in a 90-mm Petri dish. After a $24-\mathrm{h}$ incubation, emerging colonies were counted.

\section{Statistical Analysis}

Differences among optical densities in the enzyme immunoassay and ratio of colony-forming units in the treatment to control were analyzed by one-way ANOVA followed by Tukey's multiple range test. A probability of $P<0.05$ was considered significant.

\section{RESULTS}

The eluate from the Sep-Pak cartridges was examined with competitive enzyme immunoassay to confirm the presence of LAP peptide in the milk. Optical density in the eluate was less $(P<0.05)$ compared with the buffer without milk components (Figure 1),

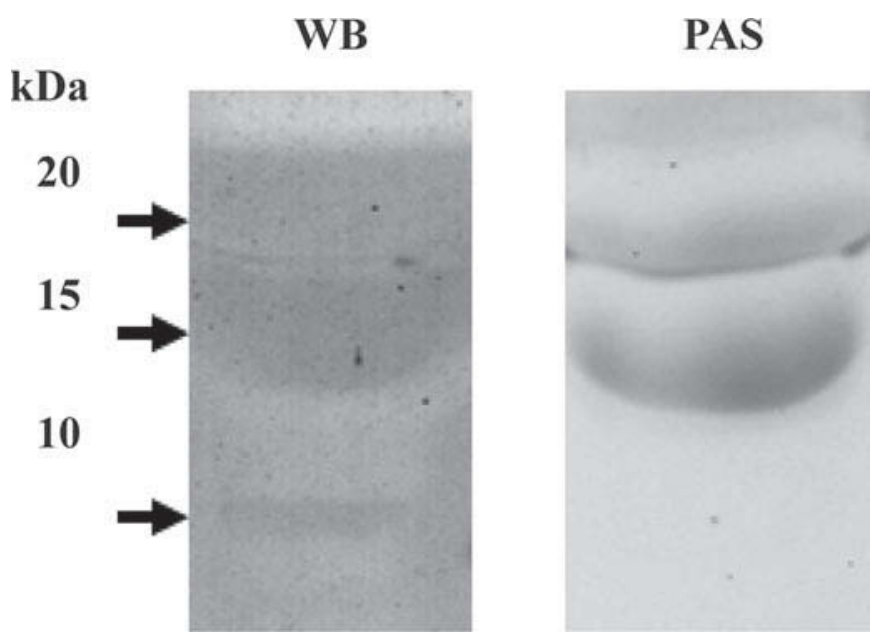

Figure 2. Western blotting with lingual antimicrobial peptide antibody (WB) and periodic acid-Schiff staining (PAS) of bovine milk. Three bands $(8,14$, and $17 \mathrm{kDa}$ : arrows) can be seen in the immunoblotting. Two bands (14 and $17 \mathrm{kDa}$ ) were positive for periodic acidSchiff staining.

indicating that immunoreactive peptide was present in the milk. Further, Western blotting analysis showed 3 immunoreactive bands of approximately 8, 14, and 17 $\mathrm{kDa}$ (Figure 2). These molecular weights were heavier than the predicted size of mature LAP peptide $(4 \mathrm{kDa})$. Therefore, carbohydrate staining was conducted following PAGE to examine the possibility of glycosylation of the LAP peptide. Two bands of approximately 14 and $17 \mathrm{kDa}$ were found periodic acid-Schiff reaction positive (Figure 2).

The eluate of the Sep-Pak cartridges was applied to an LAP antibody-coupled affinity column to isolate the LAP peptide. Processing $60 \mathrm{~mL}$ of milk resulted in the isolation of $62 \mu \mathrm{g}$ of LAP peptide after affinity purification. Therefore, the average concentration of LAP peptide in the milk sample was $1 \mu \mathrm{g} / \mathrm{mL}$. The affinity column eluate was examined with competitive enzyme immunoassay. As the eluate was diluted up to 64 times, optical density increased $(P<0.05$, Figure 3$)$, which meant concentration decreased with greater dilution.

The antimicrobial activity of the affinity eluate was investigated. In the radial diffusion plate assay, the eluate inhibited E. coli proliferation (Figure 4A). The quantitative antimicrobial activity method found the colony-forming unit count of eluate without dilution was low, although it increased $(P<0.05)$ by diluting it 2 or 4 times (Figure $4 \mathrm{~B}$ ).

\section{DISCUSSION}

After removal of fat and casein, the milk sample was subjected to a competitive enzyme immunoassay to confirm the presence of LAP peptide. The immunoreactive 


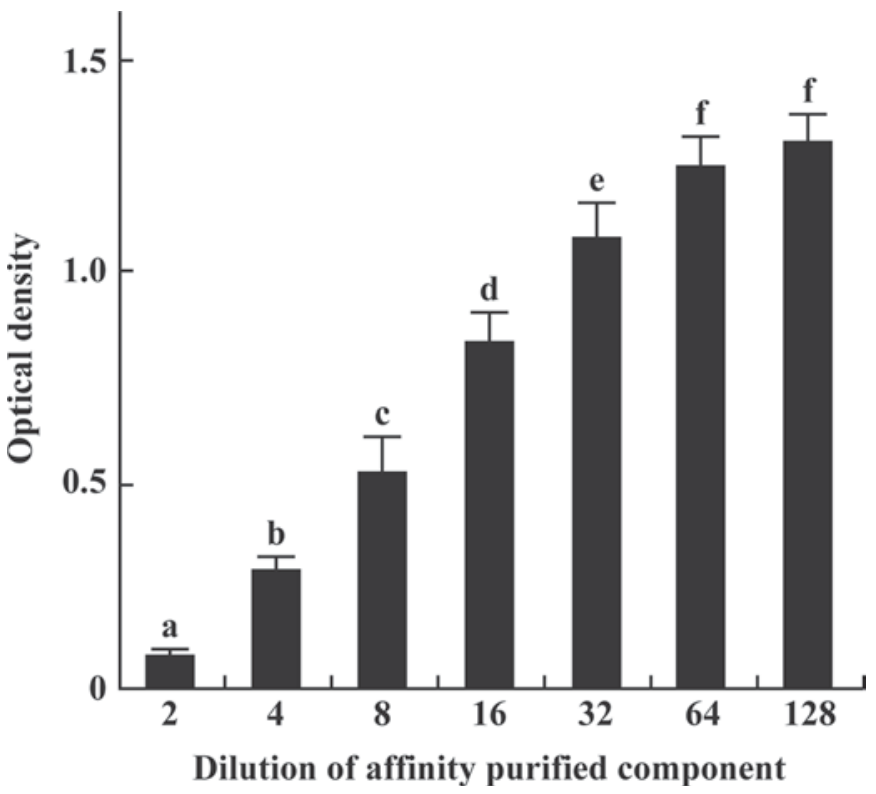

Figure 3. The competitive enzyme immunoassay of milk affinity purified with a lingual antimicrobial peptide antibody-coupled column. Affinity eluate was diluted 2 to 128 times and assayed $(n=3)$. Bars represent mean $\pm \mathrm{SD}$. ${ }^{\mathrm{a}-\mathrm{f}}$ Different letters indicate significant difference in optical densities between groups $(P<0.05)$.

component of LAP antibody was found, suggesting that milk contained LAP peptide. The eluate of the LAP antibody-coupled affinity column showed competitive immunoreaction in the enzyme immunoassay. Further, the antimicrobial activity against $E$. coli was found in the affinity column eluate. These results indicate that functional LAP peptide was found in the bovine milk. Jia et al. (2001) and Armogida et al. (2004) reported that abundant human $\beta$-defensin-1 and 2 , respectively, were found in human breast milk at concentrations of 1 to $10 \mu \mathrm{g} / \mathrm{mL}$. In the present study, the concentration of LAP peptide ( $1 \mu \mathrm{g} / \mathrm{mL}$ or more) was similar to that of human $\beta$-defensin- 1 . Human $\beta$-defensin- 1 and 2 in breast milk and breast tissue have broad-spectrum protective functions for the mother against bacteria (Jia et al., 2001; Armogida et al., 2004). The $\beta$-defensin had an impact on neonatal immunity through immunomodulatory effects. It remains to be elucidated whether or not LAP peptide in bovine milk has a similar role.

Immunoreaction in the electroblotting membrane showed 3 bands at 8,14 , and $17 \mathrm{kDa}$, which were much heavier than that of the predicted size of mature LAP peptide (4 kDa, Schonwetter et al., 1995). One of the possibilities was that the propeptide form of LAP is secreted into the milk rather than the mature counterpart. Canty et al. (2006) found that some proteins such as procollagen may be secreted in the propeptide form. Extracellular secretion occurs when the propeptide is released before the detachment of the signal peptide
A
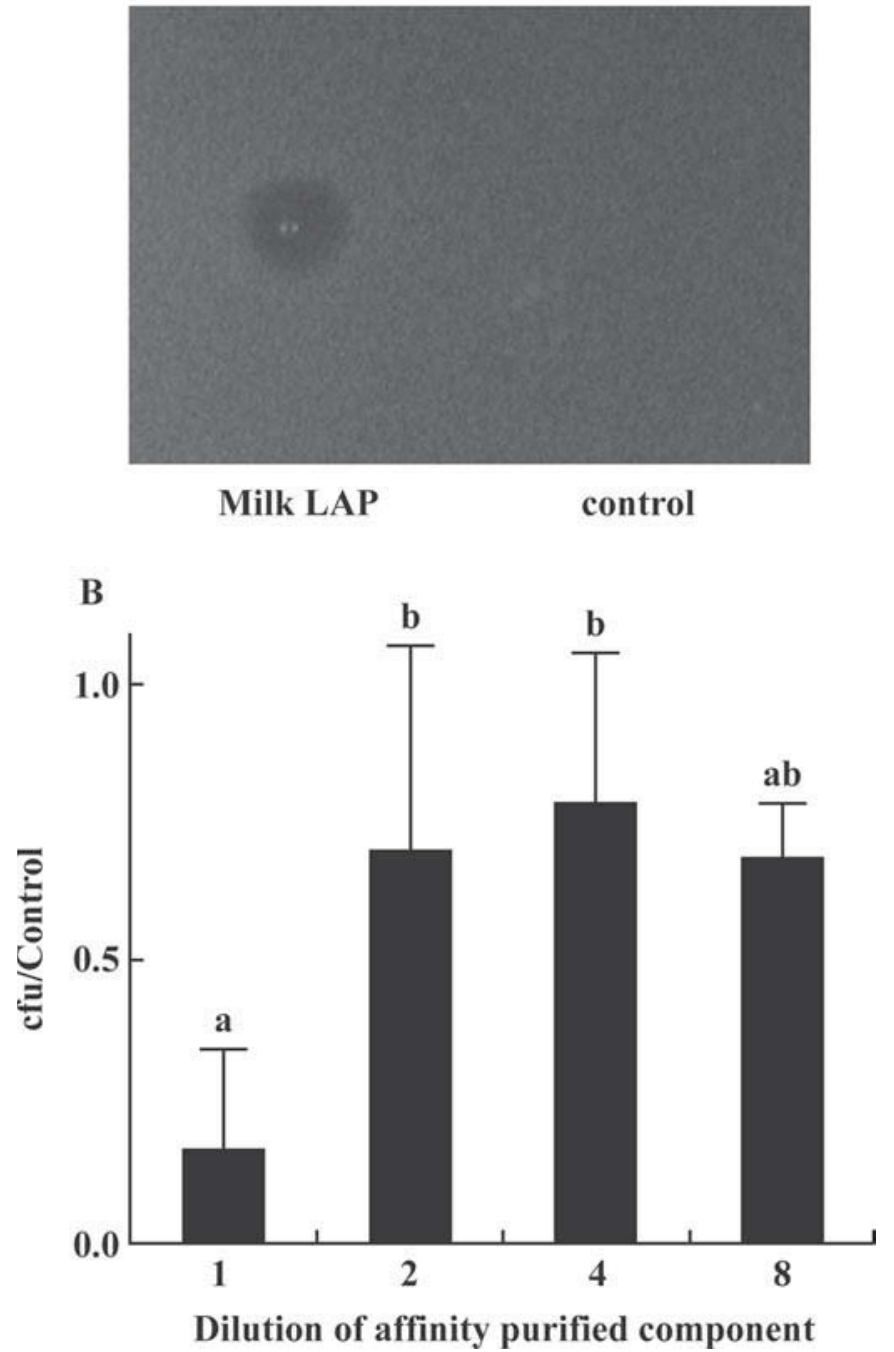

Figure 4. Antimicrobial activity of milk protein that has been affinity purified with lingual antimicrobial peptide (LAP) antibody-coupled column. A) Radial diffusion plate assay. Milk LAP: milk contents after affinity purification. Control: phosphate buffer without LAP. B) Examination of colony-forming units. Affinity purified LAP was diluted 1 to 8 times followed by assessment of antimicrobial activity (n $=3$ ). Vertical axis expresses ratio of colony-forming units of sample to that of phosphate buffer without LAP. Bars represent mean \pm SD. ${ }^{a, b}$ Different letters indicate a significant difference in ratios between dilutions $(P<0.05)$.

from the functioning protein (Dommett et al., 2005). The propeptide form of LAP had a molecular weight of 7 to $8 \mathrm{kDa}$ (Schonwetter et al., 1995) that was almost identical to the lowermost band detected in the present study. Alternatively, it was assumed that the LAP was glycosylated because the macaque $\beta$-defensin, DEFB126, was reported to include carbohydrate moiety (Yudin et al., 2005). To investigate this possibility, the gel was stained using the periodic acid-Schiff reaction. Positive carbohydrate staining resulted in the 14 and $17 \mathrm{kDa}$ bands, suggesting that 2 kinds of glycosylated 
LAP with different molecular weights of 14 and $17 \mathrm{kDa}$ exist in bovine milk.

Mastitis is one of most serious and common diseases in dairy cows. When bacteria invade the mammary glands, many kinds of immune cells and components gather to defend the host organism. The LAP is one of these immune components and exhibited direct action against bacteria. Swanson et al. (2004) found a positive relationship between SCC in milk and LAP mRNA expression and localization of mRNA in epithelial cells of mastitic tissue by in situ hybridization. Expression of LAP peptide in the mammary tissue increased after $E$. coli inoculation (Petzl et al., 2008). The present study found that LAP was present in the milk and has antimicrobial activity. Therefore, it would be interesting to examine whether IMI stimulates the secretion of LAP into milk and what causes its increased concentration in milk. Bovine milk containing functional LAP-like substances that exert antimicrobial activity for human health and the dairy industry has important nutritional and hygienic implications.

\section{ACKNOWLEDGMENTS}

We thank Lawrence M. Liao (Graduate School of Biosphere Science, Hiroshima University, HigashiHiroshima, Japan) for his critical reading of our manuscript.

\section{REFERENCES}

Armogida, S. A., N. M. Yannaras, A. L. Melton, and M. D. Srivastava. 2004. Identification and quantification of innate immune system mediators in human breast milk. Allergy Asthma Proc. 25:297304.

Bellamy, W. R., H. Wakabayashi, M. Takase, K. Kawase, S. Shimamura, and M. Tomita. 1993. Role of cell-binding in the antibacterial mechanism of lactoferricin B. J. Appl. Bacteriol. 75:478-484.

Bushe, T., and S. P. Oliver. 1987. Natural protective factors in bovine mammary secretions following different methods of milk cessation. J. Dairy Sci. 70:696-704.

Cagatay, T. I., and J. G. Hickford. 2008. Glycosylation of type-IV fimbriae of Dichelobacter nodosus. Vet. Microbiol. 126:160-167.

Canty, E. G., T. Starborg, Y. Lu, S. M. Humphries, D. F. Holmes, R S. Meadows, A. Huffman, E. T. O'Toole, and K. E. Kadler. 2006. Actin filaments are required for fibripositor-mediated collagen fibril alignment in tendon. J. Biol. Chem. 281:38592-38598.

Chandan, R. C., K. M. Shahani, and R. G. Holly. 1964. Lysozyme content of human milk. Nature 204:76-77.

Diamond, G., M. Zasloff, H. Eck, M. Brasseur, W. L. Maloy, and C. L. Bevins. 1991. Tracheal antimicrobial peptide, a cysteine-rich peptide from mammalian tracheal mucosa: Peptide isolation and cloning of a cDNA. Proc. Natl. Acad. Sci. USA 88:3952-3956.

Dommett, R., M. Zilbauer, J. T. George, and M. Bajaj-Elliott. 2005. Innate immune defence in the human gastrointestinal tract. Mol. Immunol. 42:903-912.

Ganz, T. 2003. Defensins: Antimicrobial peptides of innate immunity. Nat. Rev. Immunol. 3:710-720.
Ganz, T., M. E. Selsted, D. Szklarek, S. S. Harwig, K. Daher, D. F. Bainton, and R. I. Lehrer. 1985. Defensins. Natural peptide antibiotics of human neutrophils. J. Clin. Invest. 76:1427-1435.

Goldammer, T., H. Zerbe, A. Molenaar, H. J. Schuberth, R. M. Brunner, S. R. Kata, and H. M. Seyfert. 2004. Mastitis increases mammary mRNA abundance of $\beta$-defensin 5 , toll-like-receptor 2 (TLR2), and TLR4 but not TLR9 in cattle. Clin. Diagn. Lab. Immunol. 11:174-185.

Isobe, N., K. Hosoda, and Y. Yoshimura. 2009. Immunolocalization of lingual antimicrobial peptide (LAP) in the bovine mammary gland. Anim. Sci. J. doi:10.1111/j.1740-0929.2009.00652.x

Jia, H. P., T. Starner, M. Ackermann, P. Kirby, B. F. Tack, and P. B. McCray Jr.. 2001. Abundant human $\beta$-defensin-1 expression in milk and mammary gland epithelium. J. Pediatr. 138:109-112.

Petzl, W., H. Zerbe, J. Günther, W. Yang, H. M. Seyfert, G. Nürnberg, and H. J. Schuberth. 2008. Escherichia coli, but not Staphylococcus aureus triggers an early increased expression of factors contributing to the innate immune defense in the udder of the cow. Vet. Res. $39: 18$

Polis, B. D., and H. W. Shmukler. 1953. Crystalline lactoperoxidase. I. Isolation by displacement chromatography. II. Physicochemical and enzymatic properties. J. Biol. Chem. 201:475-500.

Schagger, H., and G. von Jagow. 1987. Tricine-sodium dodecyl sulfatepolyacrylamide gel electrophoresis for the separation of proteins in the range from 1 to $100 \mathrm{kDa}$. Anal. Biochem. 166:368-379.

Schonwetter, B. S., E. D. Stolzenberg, and M. A. Zasloff. 1995. Epithelial antibiotics induced at sites of inflammation. Science 267:1645-1648.

Selsted, M. E., and A. J. Ouellette. 2005. Mammalian defensins in the antimicrobial immune response. Nat. Immunol. 6:551-557.

Selsted, M. E., Y. Q. Tang, W. L. Morris, P. A. McGuire, M. J. Novotny, W. Smith, A. H. Henschen, and J. S. Cullor. 1993. Purification, primary structures, and antibacterial activities of $\beta$-defensins, a new family of antimicrobial peptides from bovine neutrophils. J. Biol. Chem. 268:6641-6648.

Singh, K., S. R. Davis, J. M. Dobson, A. J. Molenaar, T. T. Wheeler, C. G. Prosser, V. C. Farr, K. Oden, K. M. Swanson, C. V. Phyn, D. L. Hyndman, T. Wilson, H. V. Henderson, and K. Stelwagen. 2008. cDNA microarray analysis reveals that antioxidant and immune genes are upregulated during involution of the bovine mammary gland. J. Dairy Sci. 91:2236-2246.

Stolzenberg, E. D., G. M. Anderson, M. R. Ackermann, R. H. Whitlock, and M. Zasloff. 1997. Epithelial antibiotic induced in states of disease. Proc. Natl. Acad. Sci. USA 94:8686-8690.

Swanson, K., S. Gorodetsky, L. Good, S. Davis, D. Musgrave, K. Stelwagen, V. Farr, and A. Molenaar. 2004. Expression of a $\beta$-defensin mRNA, lingual antimicrobial peptide, in bovine mammary epithelial tissue is induced by mastitis. Infect. Immun. 72:7311-7314.

Tarver, A. P., D. P. Clark, G. Diamond, J. P. Russell, H. ErdjumentBromage, P. Tempst, K. S. Cohen, D. E. Jones, R. W. Sweeney, M. Wines, S. Hwang, and C. L. Bevins. 1998. Enteric $\beta$-defensin: Molecular cloning and characterization of a gene with inducible intestinal epithelial cell expression associated with Cryptosporidium parvum infection. Infect. Immun. 66:1045-1056.

Yoshimura, Y., and J. M. Bahr. 1991. Localization of progesterone receptors in pre- and postovulatory follicles of the domestic hen. Endocrinology 128:323-330.

Yudin, A. I., C. A. Treece, T. L. Tollner, J. W. Overstreet, and G. N. Cherr. 2005. The carbohydrate structure of DEFB126, the major component of the cynomolgus macaque sperm plasma membrane glycocalyx. J. Membr. Biol. 207:119-129.

Zasloff, M. 1987. Magainins, a class of antimicrobial peptides from Xenopus skin: Isolation, characterization of two active forms, and partial cDNA sequence of a precursor. Proc. Natl. Acad. Sci. USA $84: 5449-5453$. 